\title{
CLINICAL AND HÆMODYNAMIC PATTERNS IN ENDOMYOCARDIAL FIBROSIS
}

\author{
BY
}

\section{J. P. SHILLINGFORD* AND K. SOMERS}

From the Department of Medicine, Makerere College and Mulago Hospital, Kampala, Uganda, and the Postgraduate Medical School of London

Received February 23, 1961

In recent years endomyocardial fibrosis has attracted increasing attention as an important cause of heart disease in the equatorial parts of Africa. Bedford and Konstam (1946) described the disease in West and East African troops; Davies in 1948 documented the pathology of the condition, and Ball et al. (1954) drew attention to the frequency of its occurrence and described in detail the clinical picture. Subsequently the workers at Kampala have reported the electrocardiographic and phonocardiographic findings (Williams and Somers, 1960; Somers and Williams, 1960). Other cases have been reported in the Sudan (O'Brien, 1954); on the Gold Coast (Edington, 1954); in Ceylon (Nagaratnam and Dissanayake, 1959); in Kenya (Turner and Manson-Bahr, 1960), and in West Africa (Abrahams, 1959). The purpose of this paper is to describe the hæmodynamic findings in a series of patients with endomyocardial fibrosis and relate these to the clinical findings.

Fifteen patients were studied and the diagnosis made on clinical grounds. The ages ranged from eleven to fifty-five, seven were male and eight female. A clinical examination was made and an electrocardiogram and chest X-ray taken in all cases. Cardiac catheterization was carried out and the intracardiac pressures recorded by a Statham strain gauge connected to a transistor amplifier and photographic recorder. All measurements of pressure were made $5 \mathrm{~cm}$. below the sternal angle. In selected cases phonocardiograms were taken with a photographic recorder. The circulation time from the right atrium to the ear was measured by injecting Coomassie-blue dye into the right atrium and recording its arrival at the ear with a photoelectric cell attached to the transilluminated ear (Gabe and Shillingford, 1961).

\section{RESULTS}

As Williams et al. (1954) have so well described, the disease particularly affects the endocardium and myocardium of the ventricles and involves the mitral and tricuspid valves to produce valvular regurgitation (Fig. 1). The lesions may occur separately or in any combination and the following cases, taken from the series, illustrate various ways in which the hæmodynamic pattern may be disturbed.

Case 10. Prominent Right Ventricular Involvement. African boy, aged 12 (Rundi tribe). For three months there had been swelling of abdomen, facial œdema, and œdema of the legs. There was no history of dyspnœa, cough, or palpitation, and none of rheumatic or other disease. The ascites only responded to frequent tapping.

On examination, the patient's face was swollen and he had gross œdema of the legs and ascites (Fig. 2). The pulse was regular at 100 a minute, and the blood pressure was 90/60. The jugular venous pressure was 

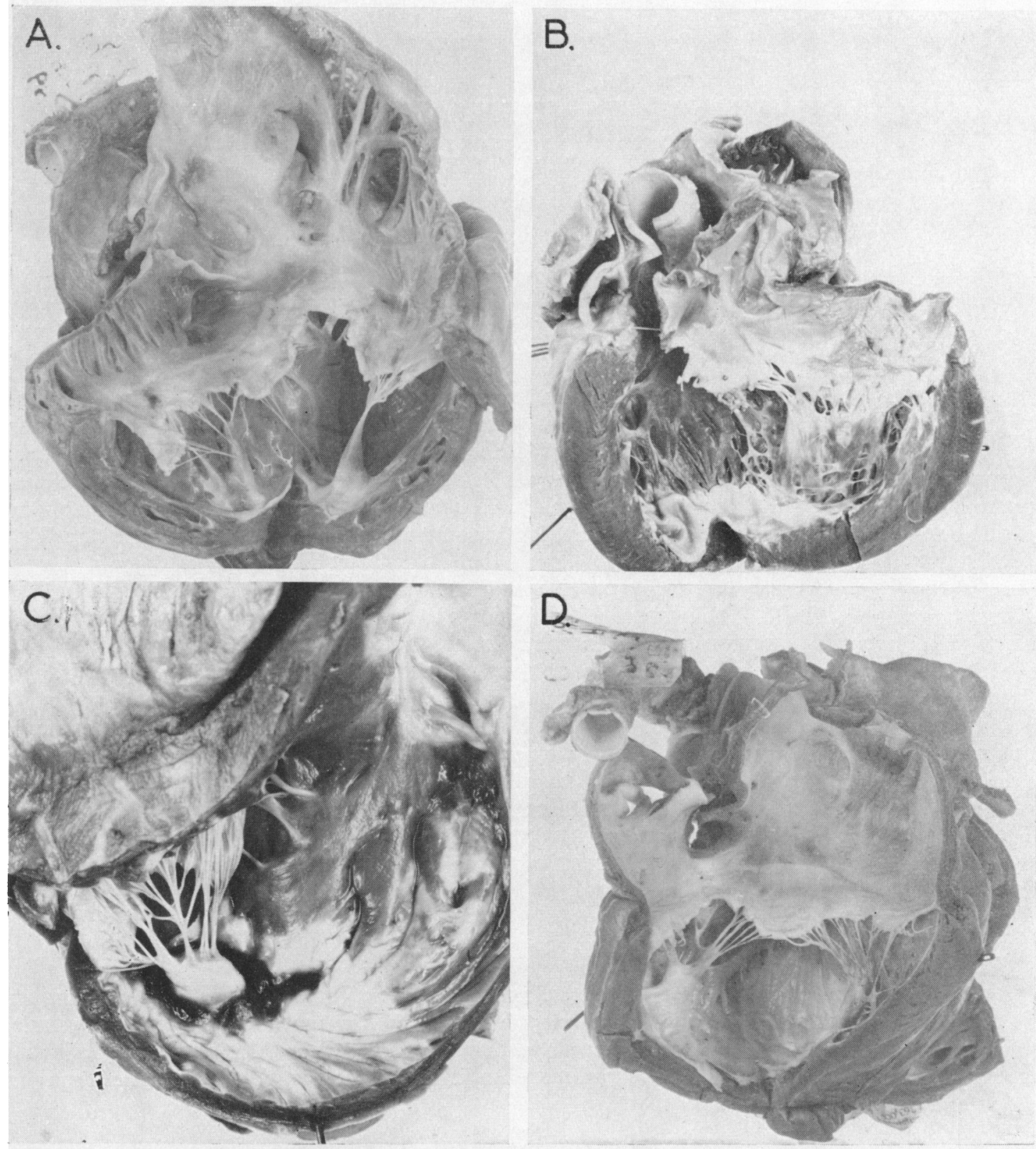

FIG. 1.- Hearts taken at necropsy from four cases of endomyocardial fibrosis showing: (A) endocardial fibrosis of the right ventricle with normal tricuspid valve; (B) endocardial fibrosis of the left ventricle involving the mitral valve; (C) endomyocardial fibrosis of the right ventricle involving the papillary muscle of the tricuspid valve; (D) endocardial fibrosis of the left ventricle with normal mitral valve. (By kind permission of Professor J. N. P. Davies.) 


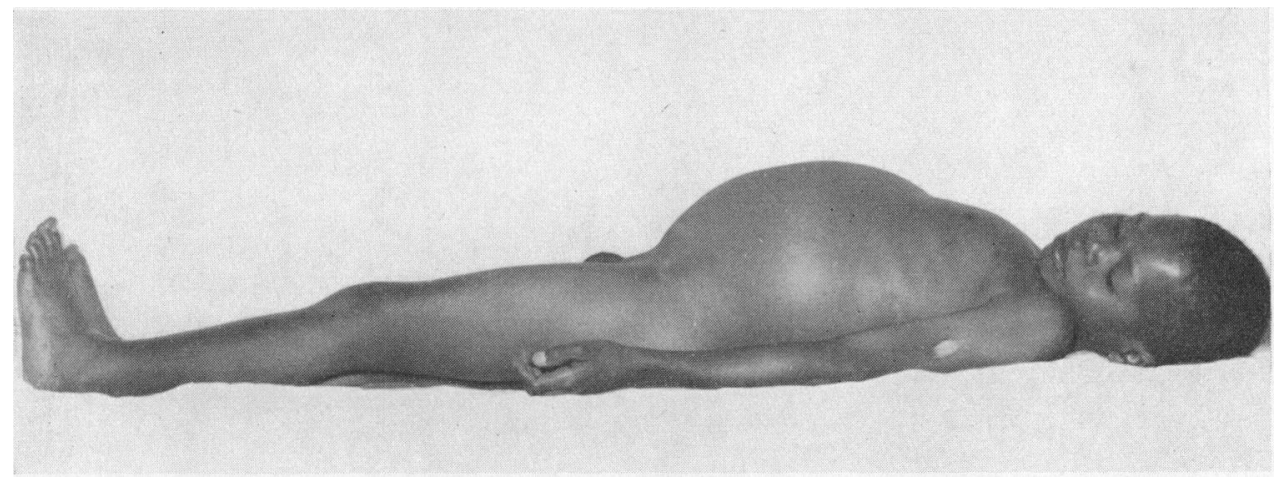

FIG. 2.-Case 10. Facial swelling, prominent liver enlargement and ascites are striking features of right ventricular obstruction from endomyocardial fibrosis.

raised to the lobe of the ear with the patient sitting at an angle of $45^{\circ}$ and showed a positive systolic pulsation. The apex beat was in the fifth space and the apical impulse appeared to be normal. The right ventricular pulsation was not increased. The pulmonary second sound was increased, and there was a loud right ventricular third sound (Fig. 3). The liver was enlarged four fingers' breadth below the costal margin and was firm and tender. The spleen was felt two fingers' breadth below the left costal margin.

The electrocardiogram showed right bundlebranch block with inversion or flattening of the $T$ waves in the chest leads (Fig. 4). The X-ray of the chest showed a greatly enlarged cardiac shadow due particularly to enlargement of the left and right atria (Fig. 5).

Cardiac Catheterization. The pulmonary capillary pressure was $16 / 10 \mathrm{~mm}$. $\mathrm{Hg}$. The pulmonary arterial pressure was $22 / 15$, the right ventricular $22 / 15$, and the right atrial $18 / 10$. The right ventricular pressure pulse was grossly distorted and resembled that obtained from the right atrium, and it would appear that the right ventricle was contributing little to the circulation (Fig. 6). The right atrial pulse showed an impaired $X$ descent that was compatible with the presence of tricuspid regurgitation. The right atrium to ear circulation time was not increased at 8.5 seconds.

Case 8. Predominant Mitral Regurgitation. An African man, aged 18 (Ganda tribe). His history was of præcordial ache for one year, cough for three months, and dyspnœa and palpitation. There was

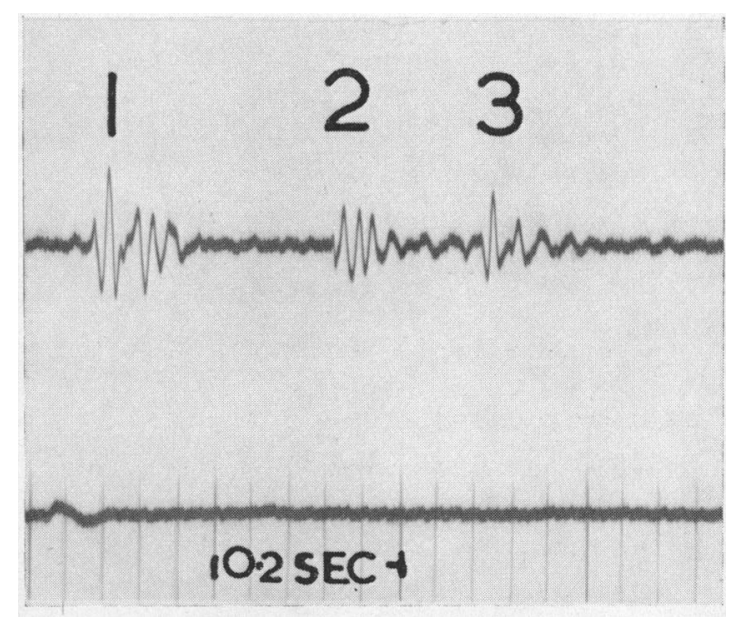

FIG. 3.-Case 10. Phonocardiogram recorded at lower end of sternum, showing third heart sound. no history of rheumatic fever.

On examination, the patient was orthopnœic but there was no œdema. The pulse was regular at 100 a minute and the blood pressure was $100 / 70$. The jugular venous pressure was not raised. The apex beat was in the seventh interspace in the anterior axillery line and there was a greatly increased left ventricular thrust. There was a systolic murmur (Grade V) with thrill best observed at the apex and radiating into the axilla. The systolic murmur included the aortic second sound and there was a low pitched early diastolic murmur with a third heart sound at the apex (Fig. 7). Crepitations were present at the bases of both lung fields. The liver was enlarged four fingers' breadth, firm, and not tender, and the spleen enlarged one finger breadth below the costal margin. The electrocardiogram showed great left ventricular hypertrophy (Fig. 8). The X-ray of the chest showed generalized enlargement of the cardiac shadow with a great increase in size of the left atrium (Fig. 9). 


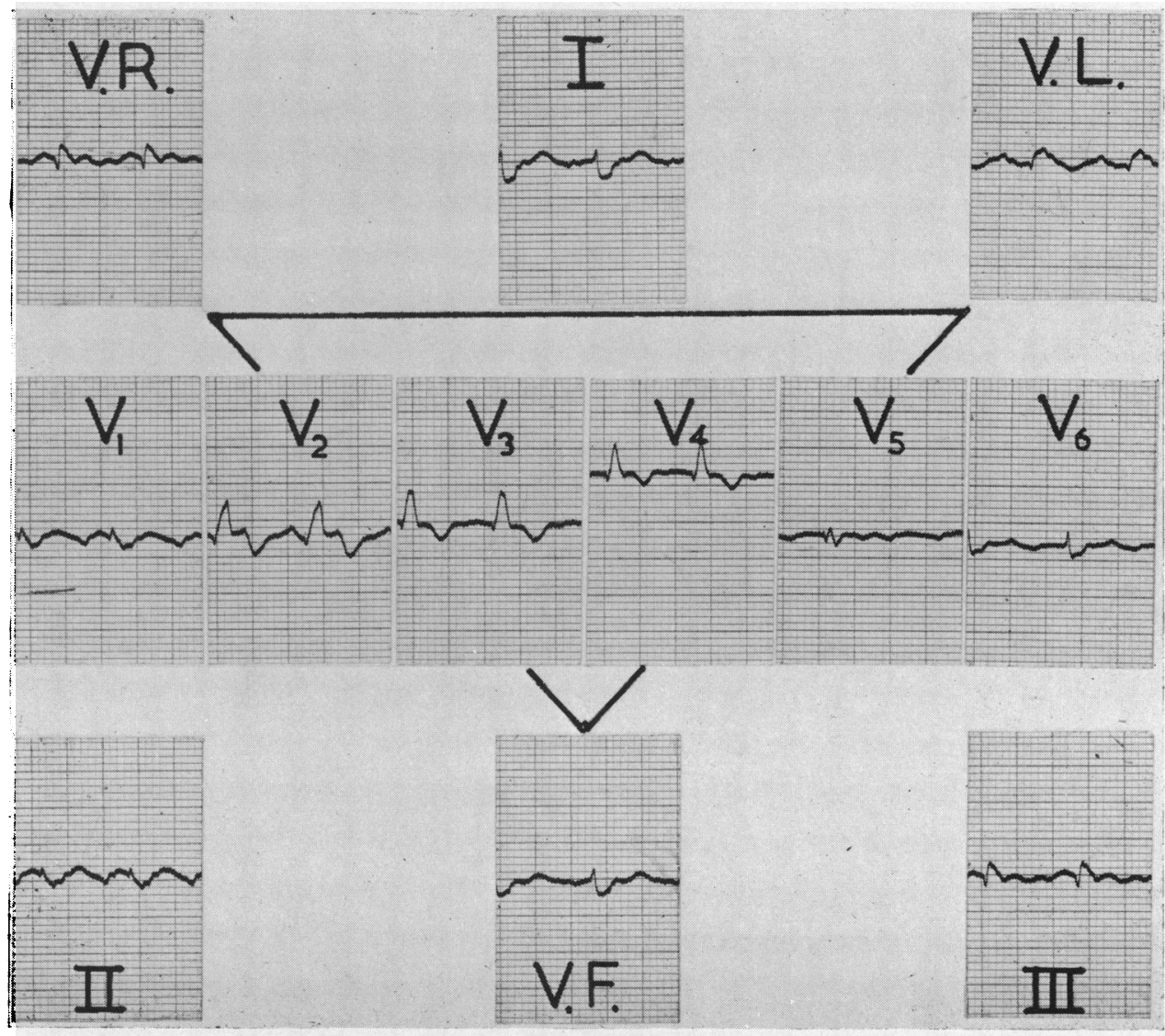

FIG. 4.-Case 10. Electrocardiogram showing right bundle-branch block and abnormal $\mathrm{T}$ waves.

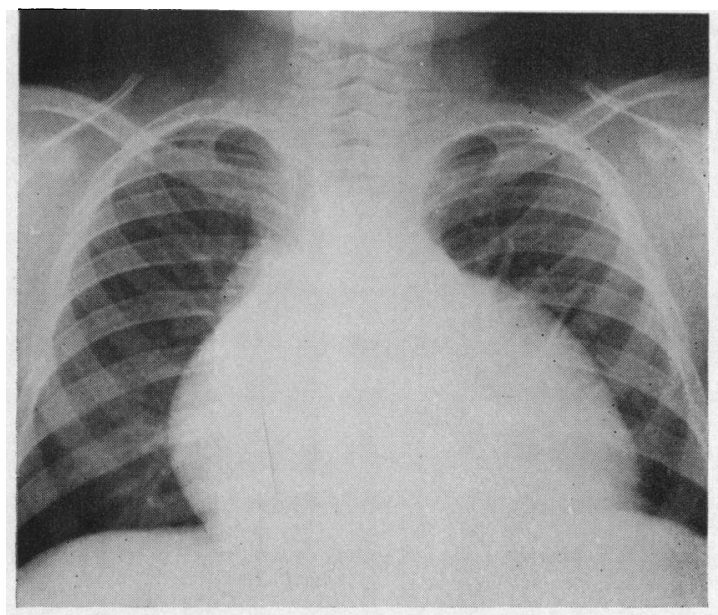

FIG. 5.-Case 10. Radiograph of chest showing enlarged heart with great right and left atrial enlargement. 


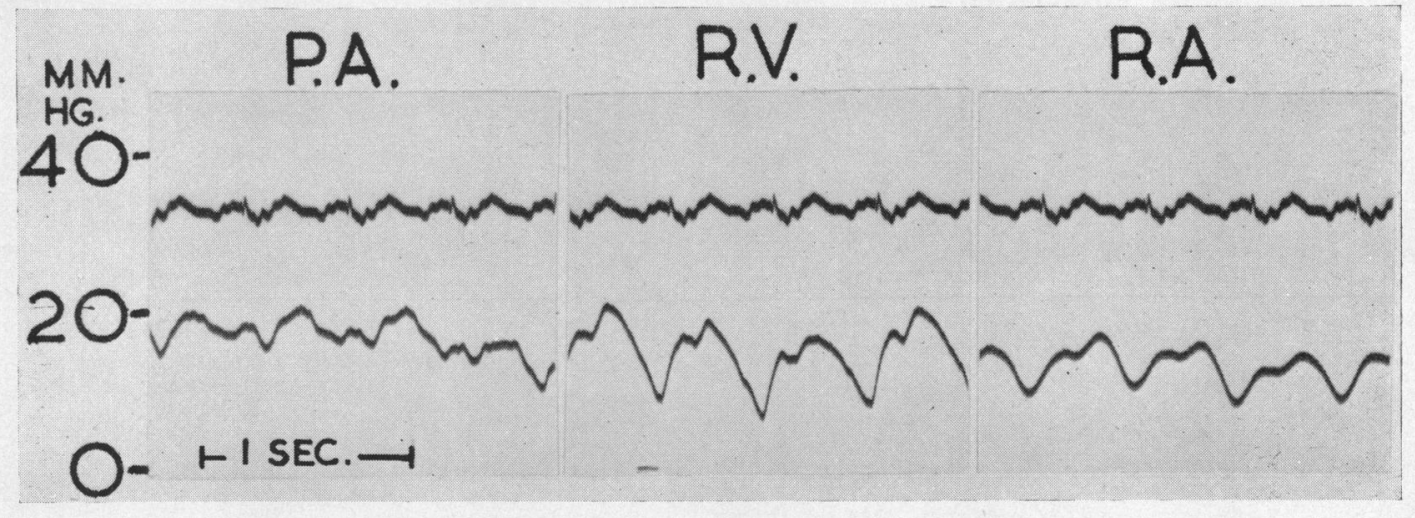

FIG. 6.--Case 10. Pressure tracings taken at the time of cardiac catheterization (PA.=pulmonary artery. $\mathrm{RV}=$ right ventricle. $\mathrm{RA}=$ right atrium).

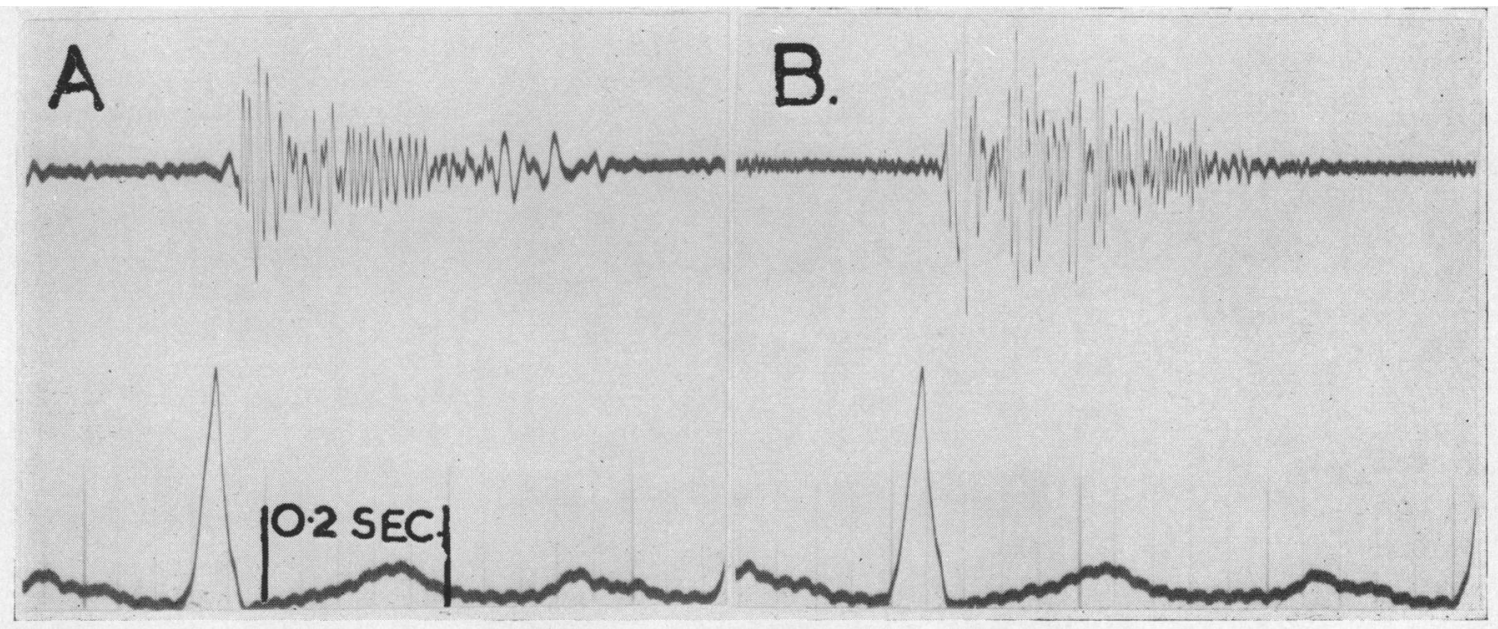

Fig. 7.--Case 8. Phonocardiogram taken from apex of heart ((A) low frequency, (B) medium frequency tracing), showing systolic murmur, early diastolic murmur, and probable third sound.

Cardiac Catheterization. The pulmonary capillary pressure was raised $(33 / 10 \mathrm{~mm}$. Hg.) with a predominant systolic pulsation. The pulmonary arterial pressure was moderately raised at $57 / 25$ as was the right ventricular systolic at 57; the right ventricular end diastolic and the right atrial pressures were within normal limits (Fig. 10). The right atrium to ear circulation time was 6.5 seconds.

Case 11. Right Ventricular Involvement with Tricuspid Regurgitation. African man, aged 28 (Ruanda tribe). For three months he had had cough and dyspnœe followed by nocturnal dyspnœa. The patient complained of pain in the region of the liver, palpitation, and swelling of the legs. There was no history of rheumatic infection.

On examination, the patient was orthopnœic with considerable œdema of the legs and ascites. The jugular venous pressure was raised to the angle of the jaw (sitting at $45^{\circ}$ ) and showed a positive systolic pulsation. The pulse was regular at 80 a minute and the blood pressure was 110/70. The apex beat was in the sixth interspace in the mid-clavicular line and there was a marked right ventricular thrust. The pulmonary second sound was increased. At the lower end of the sternum there was a pansystolic murmur which radiated to the right of the sternum but not to the axilla. A third heart sound was present at the lower 


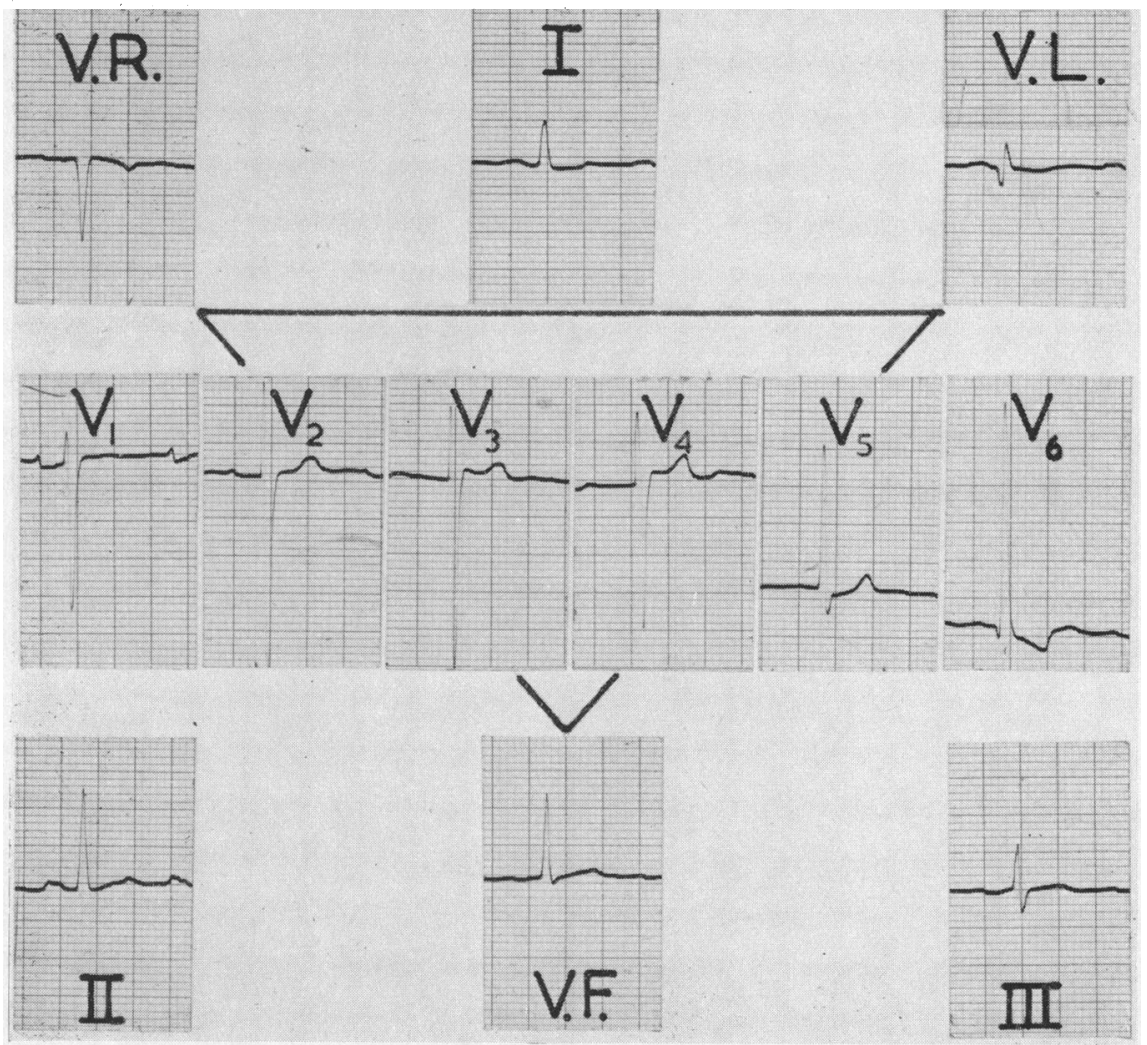

Fig. 8.-Case 8. Electrocardiogram showing left ventricular hypertrophy.

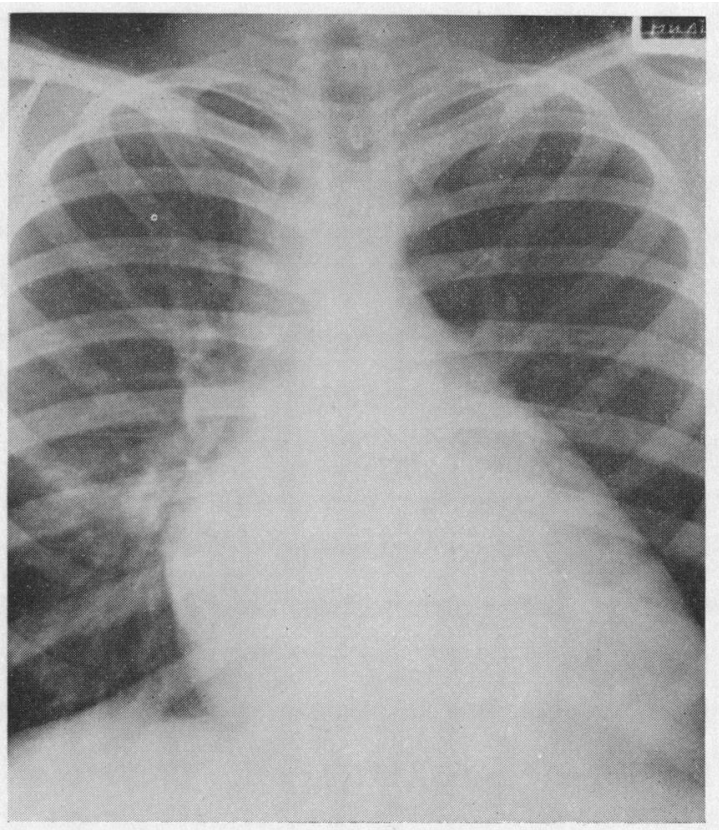

Fig. 9.-Radiograph of the chest, showing enlargement of the heart, especially of the left atrium. 


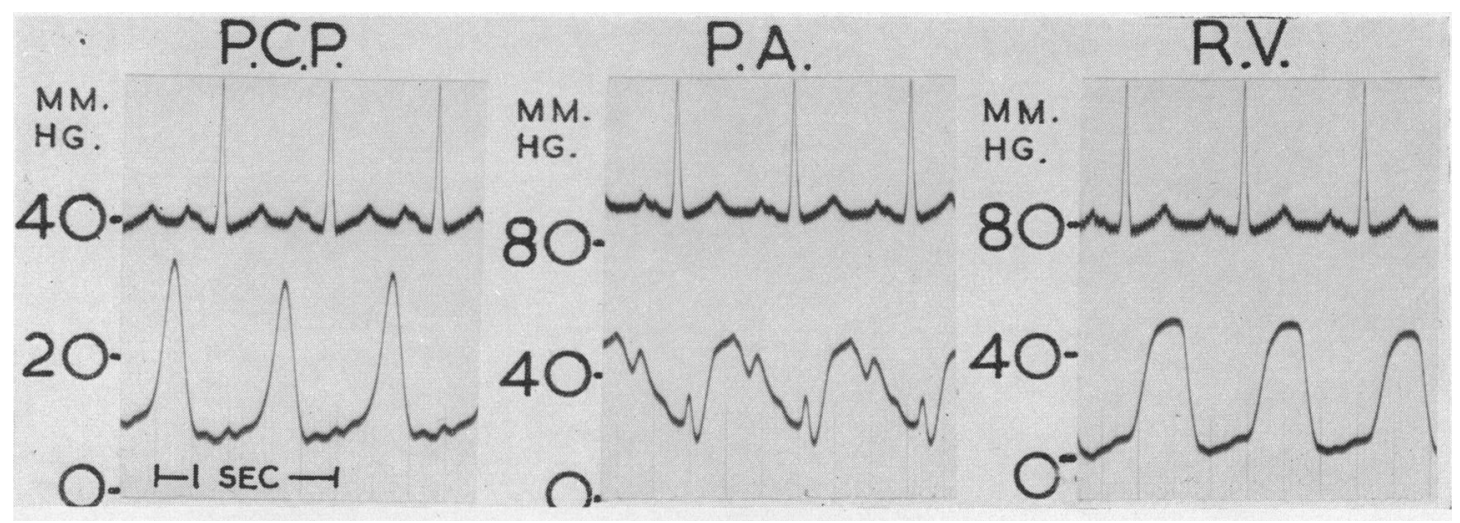

Fig. 10.-Case 8. Pressure tracings taken at the time of cardiac catheterization, showing positive systolic pulsation in the pulmonary capillary tracing and raised pulmonary arterial and right ventricular pressure (P.C.P. = pulmonary capillary pressure. $\quad$ P.A. $=$ pulmonary artery. $R V=$ right ventricle).

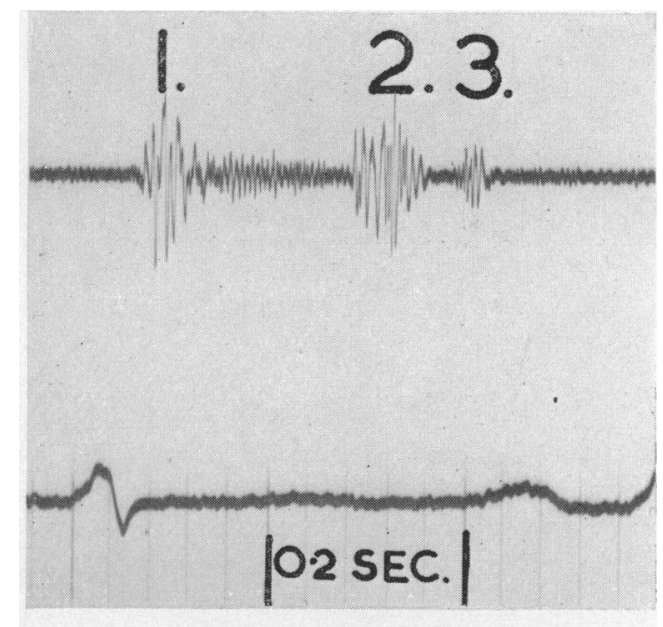

Fig. 11.-Case 11. Phonocardiogram taken at lower end of sternum, showing systolic murmur and third heart sound.

end of the sternum (Fig. 11). The liver was tender, enlarged five fingers' breadth below the costal margin, and pulsating. The spleen was felt two fingers' breadth below the costal margin.

The electrocardiogram showed inverted $T$ waves in all the chest leads (Fig. 12). The X-ray showed generalized enlargement of the cardiac shadow, with a greatly enlarged right atrium (which was confirmed at the time of cardiac catheterization).

Cardiac Catheterization. The pulmonary capillary pressure was $30 / 17 \mathrm{~mm}$. $\mathrm{Hg}$ but a marked systolic pulsation was not present. The pulmonary arterial $(65 / 30)$ and right ventricular $(65 / 18)$ pressures were increased. The right atrial pressure was increased with an "a" wave of $20 \mathrm{~mm}$. $\mathrm{Hg}$, and showed markedly impaired $X$ descent and a sharp diastolic dip to $8 \mathrm{~mm}$. (Fig. 13). The circulation time from the right atrium to ear was $9 \cdot 1$ seconds. 


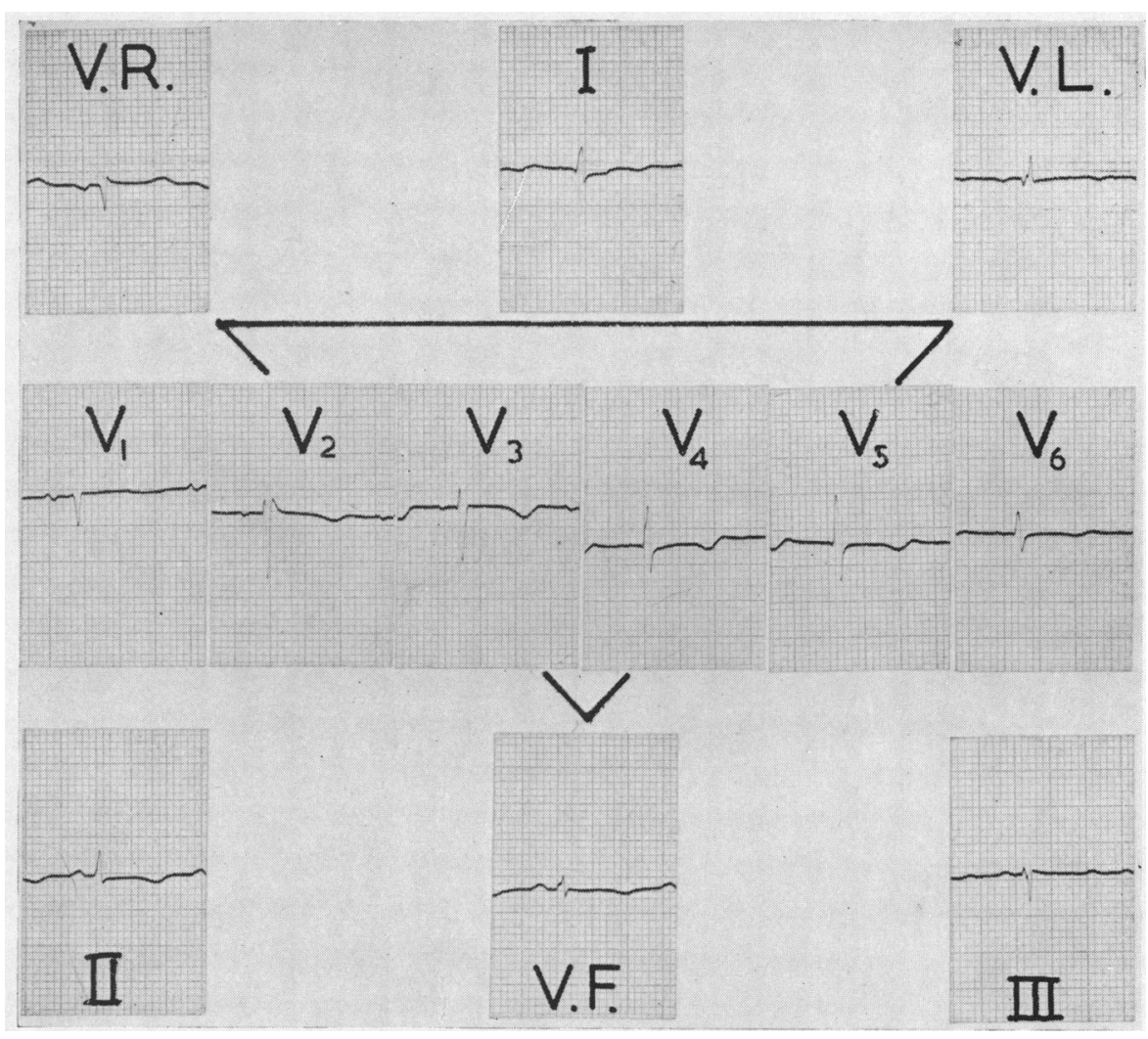

FIG. 12.-Case 11. Electrocardiogram showing inverted $\mathrm{T}$ waves in all the chest leads.

\section{Clinical Findings in Whole Group of Patients}

The clinical and hæmodynamic findings in all the patients are summarized in Table I. The history of these patients drawn from African tribes speaking different languages is often difficult to elicit but the chief complaints were of breathlessness, palpitation, œdema, and liver pain. A common treatment practised by the local African medicine men is to scarify the skin over the part of the body where there is pain or discomfort. In many cases of endomyocardial fibrosis, scarifications were present over the apex of the heart (for palpitation) and over the liver (for pain). The duration of history was approximately three months, but it must be remembered that only patients in the advanced state of the disease were seen in hospital and their recollections of time were probably not as accurate as would be the case of patients in the European population.

On examination all fifteen patients had edema of the legs and sacrum and this was severe in fourteen. Jaundice was not found in any. The pulse rate was usually raised to 90 to 100 a minute and the sphygmomanometer showed a low pulse pressure corresponding to the pulse volume which was small or within normal limits. In two patients the systolic and diastolic pressures were a little raised (150/100 and 140/110), but otherwise there was no systemic hypertension. A left ventricular heave was felt in eight patients with mitral regurgitation but in four others with this condition the sign was absent. An increase in the right ventricular pulsation was noted in ten instances in association with pulmonary hypertension. In these patients the pulmonary second sound was increased.

A third heart sound heard at the apex and thought to arise in the left ventricle was present in all the fifteen patients. In nine a third sound was heard at the lower end of the sternum and was 


$$
\text { P.A. R.V. }
$$

MM.

HG.

\section{$80-$}

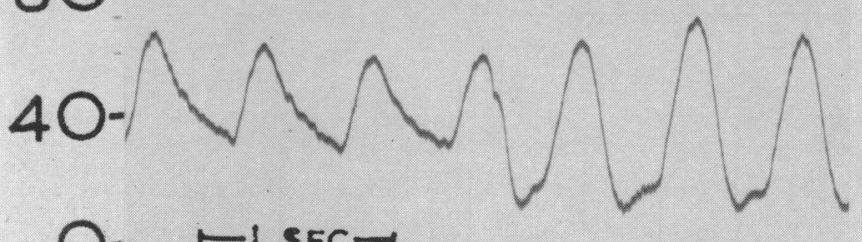

O- - -I SEC- -1

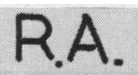

MM.
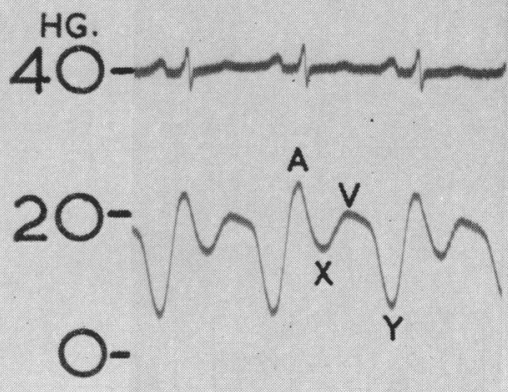

Fig. 13.-Case 11. Pressure tracings taken at the time of cardiac catheterization, showing raised pulmonary arterial and right ventricular pressure. The $\mathrm{X}$ descent is impaired with a sharp $\mathrm{Y}$ dip in the right artial tracing. (PA. = pulmonary artery. $R V .=$ right ventricle. $R A .=$ right atrium).

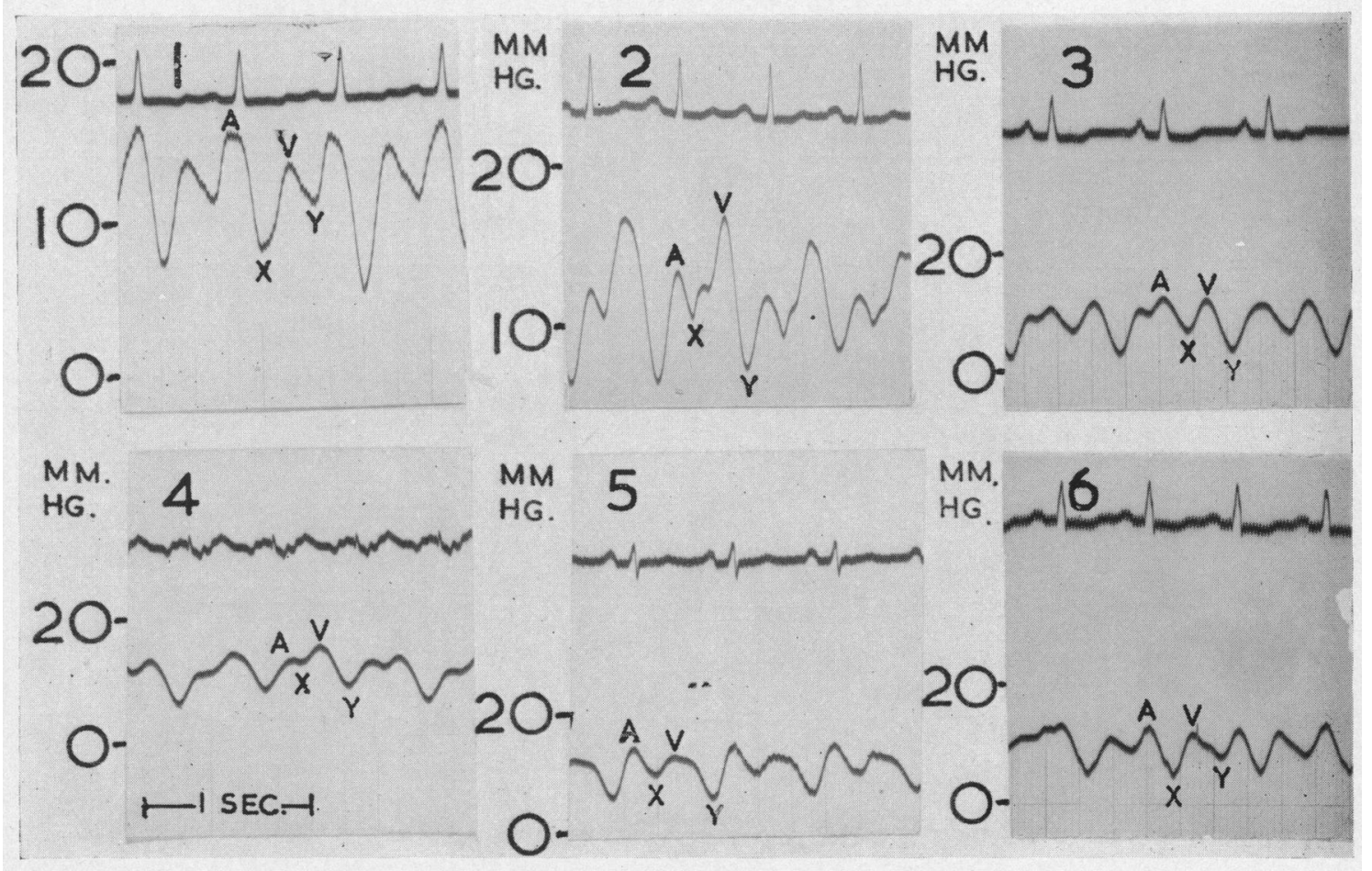

FIG. 14.-Representative right atrial pressure tracings (see text).

considered to be right ventricular in origin. The systolic murmur of mitral regurgitation was prominent in 11 patients; in one it was soft and in four accompanied by a thrill. The systolic murmur of tricuspid regurgitation was far less common and observed in only five cases. A greatly enlarged and often tender liver was found in all the patients, and ascites in all but one.

Radiography repvealed an enlarged heart in every case. The atria were especially affected; dilatation of the right was associated with the high venous pressure and of the left with mitral 
TABLE I

Summary OF Clinical

\begin{tabular}{|c|c|c|c|c|c|c|c|c|c|c|c|c|c|c|c|c|c|}
\hline ্ֻঠু & Æֶ & $\begin{array}{l}\text { Predominant } \\
\text { lesions }\end{array}$ & 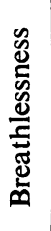 & 总 & 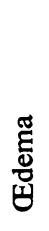 & 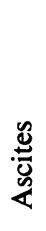 & 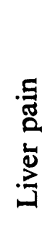 & $\begin{array}{l}\frac{\mathscr{E}}{\pi} \\
0 \\
\frac{\mathscr{m}}{3}\end{array}$ & 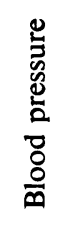 & 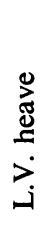 & 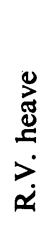 & 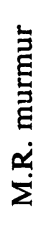 & 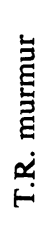 & 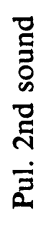 & 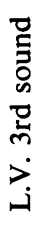 & 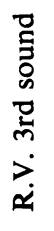 & 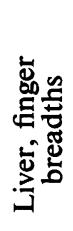 \\
\hline 1. & $\mathbf{F}$ & $\begin{array}{l}\text { Right ventricle } \\
\text { Mitral valve } \\
\text { Tricuspid valve }\end{array}$ & + & + & + & + & + & 90 & $\frac{140}{90}$ & - & - & + & - & - & + & + & 4 \\
\hline 2. & $\mathbf{F}$ & $\begin{array}{l}\text { Right ventricle } \\
\text { Left ventricle } \\
\text { Mitral valve } \\
\text { Tricuspid valve }\end{array}$ & + & + & + & + & + & 90 & $\frac{110}{90}$ & - & - & $\begin{array}{l}+ \\
+\end{array}$ & + & - & + & + & 5 \\
\hline 3. & $\mathbf{F}$ & $\begin{array}{l}\text { Left ventricle } \\
\text { Mitral valve }\end{array}$ & + & + & + & + & + & 90 & $\frac{120}{70}$ & + & + & $\begin{array}{l}+ \\
+ \\
+\end{array}$ & - & + & + & + & 4 \\
\hline 4. & $\mathbf{M}$ & $\begin{array}{l}\text { Left ventricle } \\
\text { Mitral valve }\end{array}$ & + & + & + & - & - & 96 & $\frac{100}{70}$ & + & + & $\begin{array}{l}+ \\
+ \\
+\end{array}$ & - & + & + & - & 3 \\
\hline 5. & $\mathbf{F}$ & $\begin{array}{l}\text { Mitral valve } \\
\text { Left ventricle } \\
\text { Right ventricle }\end{array}$ & + & - & + & + & + & 100 & $\frac{105}{60}$ & + & + & $\begin{array}{l}+ \\
+\end{array}$ & - & + & + & - & 4 \\
\hline 6. & $\mathbf{F}$ & $\begin{array}{l}\text { Mitral valve } \\
\text { Left ventricle }\end{array}$ & + & + & + & + & + & 90 & $\frac{120}{80}$ & - & + & $\begin{array}{l}+ \\
+ \\
+\end{array}$ & - & + & + & - & 4 \\
\hline 7. & $\mathbf{M}$ & $\begin{array}{l}\text { Mitral valve } \\
\text { Left ventricle } \\
\text { Right ventricle }\end{array}$ & + & + & + & + & + & 94 & $\frac{150}{100}$ & + & - & $\begin{array}{l}+ \\
+ \\
+\end{array}$ & - & + & + & - & 3 \\
\hline 8. & $\mathbf{M}$ & $\begin{array}{l}\text { Mitral valve } \\
\text { Left ventricle }\end{array}$ & + & + & + & \pm & + & 96 & $\frac{110}{70}$ & + & - & $\begin{array}{l}+ \\
+ \\
+\end{array}$ & - & $\begin{array}{l}+ \\
+\end{array}$ & + & - & 4 \\
\hline 9. & $\mathbf{M}$ & $\begin{array}{l}\text { Left ventricle } \\
\text { Right ventricle }\end{array}$ & 0 & 0 & + & + & 0 & 110 & $\frac{110}{80}$ & - & + & - & - & - & + & + & 5 \\
\hline 10. & $\mathbf{M}$ & $\begin{array}{l}\text { Right ventricle } \\
\text { Left ventricle }\end{array}$ & + & + & + & + & + & 85 & $\frac{90}{60}$ & - & + & - & - & - & + & + & 4 \\
\hline 11. & $\mathbf{M}$ & $\begin{array}{l}\text { Left ventricle } \\
\text { Right ventricle } \\
\text { Tricuspid valve }\end{array}$ & + & + & + & + & + & 70 & $\frac{110}{70}$ & - & + & - & $\begin{array}{l}+ \\
+\end{array}$ & + & + & + & 4 \\
\hline 12. & $\mathrm{~F}$ & $\begin{array}{l}\text { Mitral valve } \\
\text { Left ventricle } \\
\text { Right ventricle }\end{array}$ & + & + & + & + & + & 70 & $\frac{130}{80}$ & + & + & + & + & + & + & + & 3 \\
\hline 13. & $\mathbf{F}$ & $\begin{array}{l}\text { Mitral valve } \\
\text { Left ventricle } \\
\text { Right ventricle }\end{array}$ & - & - & + & + & + & 120 & $\begin{array}{r}130 \\
90\end{array}$ & + & + & $\begin{array}{l}+ \\
+ \\
+\end{array}$ & + & + & + & + & 4 \\
\hline 14. & $\mathbf{F}$ & $\begin{array}{l}\text { Mitral valve } \\
\text { Right ventricle } \\
\text { Left ventricle }\end{array}$ & + & + & + & + & + & 80 & $-\frac{140}{110}$ & + & + & $\begin{array}{l}+ \\
+ \\
+\end{array}$ & + & + & + & + & 4 \\
\hline 15. & $\mathbf{M}$ & $\begin{array}{l}\text { Right ventricle } \\
\text { Mitral valve } \\
\text { Left ventricle }\end{array}$ & - & - & + & + & + & 105 & $\begin{array}{r}100 \\
80\end{array}$ & - & - & + & - & - & + & - & 4 \\
\hline
\end{tabular}




\begin{tabular}{|c|c|c|c|c|c|c|c|c|c|c|c|c|c|}
\hline \multirow{2}{*}{ Electrocardiogram } & \multicolumn{5}{|c|}{ X-ray } & \multirow[b]{2}{*}{$\dot{0}_{\dot{0}}^{\circ}$} & \multirow[b]{2}{*}{ 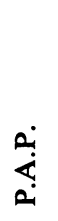 } & \multirow[b]{2}{*}{$\begin{array}{l}\dot{p} \\
\dot{x}\end{array}$} & \multicolumn{4}{|c|}{$\begin{array}{c}\text { Right atrial } \\
\text { pressure }\end{array}$} & \multirow{2}{*}{ 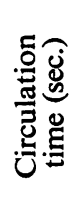 } \\
\hline & $\ddot{i}$ & $\underset{4}{i}$ & $\overrightarrow{\dot{m}}$ & $\underset{\dot{x}}{\dot{\alpha}}$ & $\underset{ن}{i}$ & & & & a & $\mathbf{x}$ & $\mathbf{v}$ & $\mathrm{y}$ & \\
\hline $\begin{array}{l}\text { Atrial fibrillation } \\
\text { Low voltage } \\
\text { Flat } \mathrm{T} \text { waves }\end{array}$ & - & + & + & $\begin{array}{l}+ \\
+\end{array}$ & - & $\frac{10}{6}$ & $\begin{array}{r}16 \\
8\end{array}$ & $\begin{array}{r}16 \\
0 \\
8\end{array}$ & 12 & 4 & 12 & 8 & $6 \cdot 4$ \\
\hline $\begin{array}{l}\text { Sinus rhythm } \\
\text { T inverted in V5, } 6\end{array}$ & $\begin{array}{l}+ \\
+\end{array}$ & $\begin{array}{l}+ \\
+\end{array}$ & + & $\begin{array}{l}+ \\
+\end{array}$ & + & - & - & - & 19 & 4 & 16 & 6 & $13 \cdot 0$ \\
\hline $\begin{array}{l}\text { Sinus rythm } \\
\text { L.V.+ } \\
\text { P. pulmonale }\end{array}$ & - & $\begin{array}{l}+ \\
+ \\
+\end{array}$ & $\begin{array}{l}\text { Bil } \\
\text { ple } \\
\text { effu }\end{array}$ & & + & $\frac{33}{20}$ & $\frac{90}{30}$ & $\begin{array}{r}90 \\
0 \\
0\end{array}$ & 15 & 0 & 15 & 0 & $7 \cdot 8$ \\
\hline $\begin{array}{l}\text { Sinus rhythm } \\
\text { L.V.t }\end{array}$ & + & $\begin{array}{l}+ \\
+ \\
+\end{array}$ & - & $\begin{array}{l}+ \\
+\end{array}$ & - & $\begin{array}{l}35 \\
16\end{array}$ & $\begin{array}{l}60 \\
35\end{array}$ & $\begin{array}{r}60 \\
2 \\
7\end{array}$ & 10 & 5 & 9 & 4 & 9.0 \\
\hline $\begin{array}{l}\text { Sinus rhythm } \\
\text { L.V.+ } \\
\text { Low T's V5, } 6\end{array}$ & $\begin{array}{l}+ \\
+\end{array}$ & + & + & $\begin{array}{l}+ \\
+\end{array}$ & + & $\begin{array}{l}29 \\
18\end{array}$ & $\frac{50}{25}$ & $\begin{array}{r}50 \\
0 \\
8\end{array}$ & - & - & - & - & $9 \cdot 0$ \\
\hline $\begin{array}{l}\text { Sinus rhythm } \\
\text { L.V.+ }\end{array}$ & - & $\begin{array}{l}+ \\
+ \\
+\end{array}$ & - & + & - & $\frac{35}{17}$ & $\begin{array}{l}45 \\
25\end{array}$ & - & - & - & - & - & - \\
\hline $\begin{array}{l}\text { Sinus rhythm } \\
\text { R.V.+T waves } \\
\text { inverted V5, } 6\end{array}$ & $\begin{array}{l}+ \\
+\end{array}$ & $\begin{array}{l}+ \\
+\end{array}$ & $\begin{array}{l}+ \\
+\end{array}$ & + & + & 27 & $\begin{array}{l}60 \\
30\end{array}$ & $\begin{array}{r}60 \\
5 \\
8\end{array}$ & 10 & 4 & 6 & 5 & 10 \\
\hline $\begin{array}{l}\text { Sinus rhythm } \\
\text { L.V.+ }\end{array}$ & + & $\begin{array}{l}+ \\
+\end{array}$ & + & + & + & $\frac{33}{10}$ & $\begin{array}{l}57 \\
25\end{array}$ & $\begin{array}{r}57 \\
0 \\
3\end{array}$ & 6 & 0 & 4 & 0 & $6 \cdot 5$ \\
\hline $\begin{array}{l}\text { Sinus rhythm } \\
T \text { inverted in } \\
\text { chest leads }\end{array}$ & - & + & + & + & - & $\frac{28}{15}$ & $\begin{array}{l}45 \\
22\end{array}$ & $\begin{array}{r}45 \\
6 \\
12\end{array}$ & 25 & 15 & 24 & 5 & 6.0 \\
\hline $\begin{array}{l}\text { Sinus rhythm } \\
\text { R.B.B.B. }\end{array}$ & - & - & - & $\begin{array}{l}+ \\
+ \\
+\end{array}$ & - & $\begin{array}{l}16 \\
10\end{array}$ & $\begin{array}{l}22 \\
15\end{array}$ & $\begin{array}{r}22 \\
8 \\
15\end{array}$ & 16 & 14 & 18 & 10 & $8 \cdot 5$ \\
\hline $\begin{array}{l}\text { Sinus rhythm } \\
\text { R.V.+ }\end{array}$ & + & $\begin{array}{l}+ \\
+\end{array}$ & + & $\begin{array}{l}+ \\
+ \\
+\end{array}$ & + & $\frac{30}{17}$ & $\frac{60}{30}$ & $\begin{array}{l}60 \\
18 \\
20\end{array}$ & 20 & 20 & 20 & 10 & $9 \cdot 1$ \\
\hline $\begin{array}{l}\text { Sinus rhythm } \\
\text { L.V.+ }\end{array}$ & \pm & + & + & + & + & $\begin{array}{l}38 \\
15\end{array}$ & $\frac{60}{22}$ & $\begin{array}{r}60 \\
2 \\
2\end{array}$ & 5 & 2 & 4 & 3 & $7 \cdot 0$ \\
\hline $\begin{array}{l}\text { Ventricular } \\
\text { extrasystoles } \\
\text { L.V.+ }\end{array}$ & - & $\begin{array}{l}+ \\
+\end{array}$ & + & $\begin{array}{l}+ \\
+\end{array}$ & + & - & - & $\begin{array}{l}55 \\
10 \\
15\end{array}$ & 15 & 14 & 16 & 11 & 8.0 \\
\hline $\begin{array}{l}\text { Sinus rhythm } \\
\text { L.V.+ }\end{array}$ & $\begin{array}{l}+ \\
+ \\
+\end{array}$ & $\begin{array}{l}+ \\
+\end{array}$ & + & $\begin{array}{l}+ \\
+\end{array}$ & + & $\begin{array}{l}25 \\
15\end{array}$ & $\begin{array}{l}58 \\
30\end{array}$ & \begin{tabular}{l|}
58 \\
12 \\
18
\end{tabular} & 12 & 6 & 9 & 9 & $14 \cdot 0$ \\
\hline $\begin{array}{l}\text { Atrial fibrillation, } \\
\text { low voltage, flat } \\
\text { T inversion chest } \\
\text { leads }\end{array}$ & - & + & - & $\begin{array}{l}+ \\
+ \\
+\end{array}$ & - & $\begin{array}{l}7 \\
4\end{array}$ & $\frac{10}{5}$ & $\begin{array}{r}10 \\
1 \\
3\end{array}$ & 8 & 5 & 7 & 7 & $10 \cdot 0$ \\
\hline
\end{tabular}




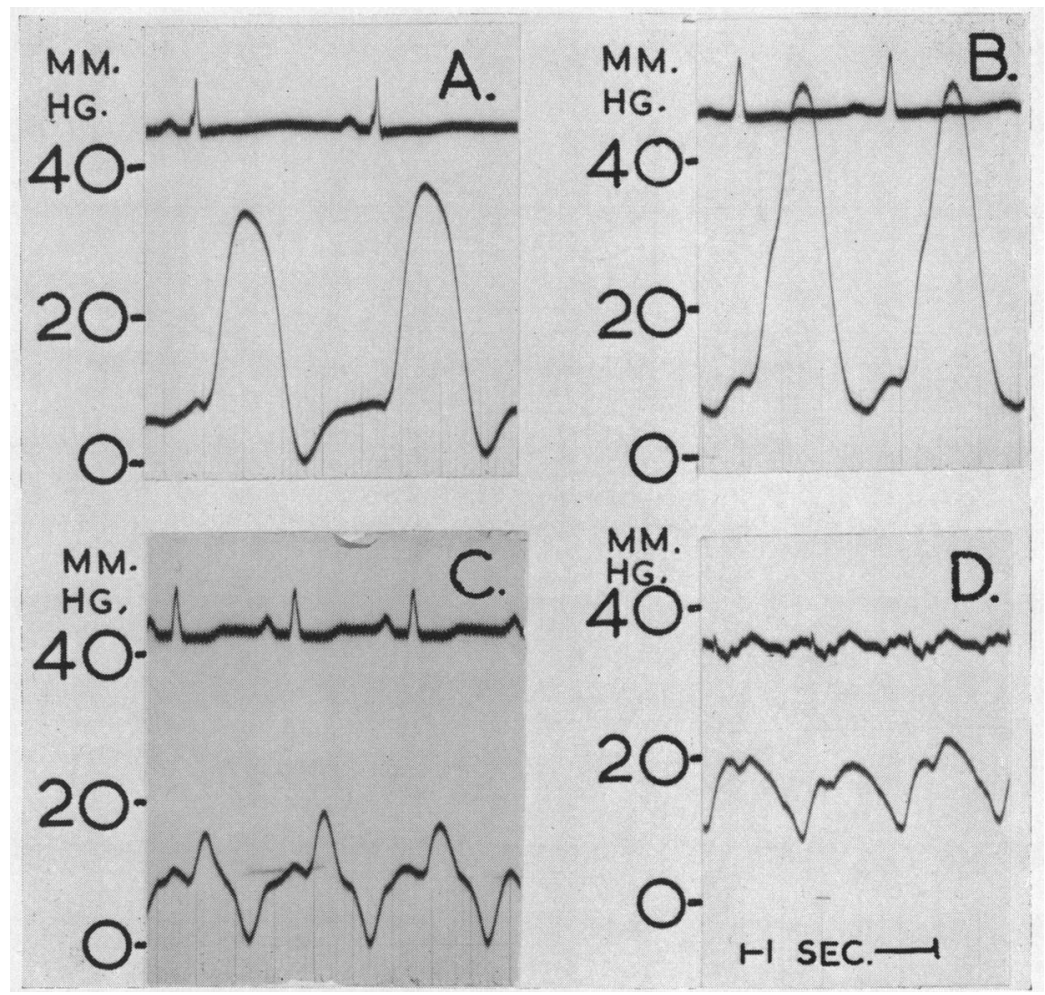

FIG. 15.-Representative right ventricular pressure tracings (see text).

regurgitation. The left ventricle was prominent in eight patients and the right judged to be enlarged in ten, especially in those with pulmonary hypertension. The pulmonary conus was likewise enlarged in nine.

Electrocardiography confirmed the presence of sinus rhythm in thirteen patients (with ventricular extrasystoles in two) and atrial fibrillation in two. $\mathbf{P}$ mitrale was present on six occasions in association with mitral regurgitation. Right ventricular preponderance was present in three and left preponderance in seven. Right bundle-branch block was found in one and non-specific flat or inverted $\mathrm{T}$ waves in thirteen out of the fifteen patients.

\section{Hamodynamic Findings in Whole Group of Patients}

The Right Atrial Pulse and Venous Pressure. The venous and right atrial pressure was significantly raised in thirteen patients ranging from a mean pressure of 6 to $20 \mathrm{~mm}$. $\mathrm{Hg}$. The right atrial pressure pulse in many cases showed the form usually associated with constriction of the right ventricle (Hansen et al., 1951) in which the mean level of the pressure was raised and the $X$ and $Y$ descents relatively increased (Fig. 14). In six cases the $\mathrm{X}$ was lower than the $\mathrm{Y}$ descent, in two it was the same, and in five did not descend so low. In the other two the right atrial pulse was not recorded for technical reasons. Although the "a" was prominent in several of the patients, and as high as $25 \mathrm{~mm}$. $\mathrm{Hg}$ in one, the rest of the pressure pulse was raised to a similar degree and in no instance was an isolated increase in the " $a$ " wave found.

In four cases with an impaired $X$ descent the murmur of tricuspid regurgitation was heard on auscultation, and in these the raised $X$ descent was thought to be due to associated tricuspid insufficiency as well as constriction of the right ventricle. 
The Right Ventricular Pressure Pulse. This pulse varied from near normal to a grossly distorted form. Fig. 12 shows a representative group of the wave forms found in our series. In nearly all the cases there was a raised end diastolic pressure with an early diastolic dip. With increasing severity, the early diastolic dip became more pronounced and the systolic pressure attenuated (Fig. $12 \mathrm{C}$ ); in the most severe form the right ventricular pulse resembled that found in the right atrium (Fig. 12D).

The Pulmonary Capillary Pressure Pulse. All elements of this pulse were raised above normal in ten of our patients. Tracings from eight patients with advanced mitral regurgitation showed a well marked positive systolic wave rising sometimes as high as $35 \mathrm{~mm}$. $\mathrm{Hg}$ (Fig. 10). The diastolic dip in patients with assumed constriction of the right ventricle was not so obvious as in the right atrial pressure pulse with constriction of the right ventricle. It was not possible by inspection of the pulmonary capillary pulse to distinguish constriction of the left ventricle from left ventricular cardiac failure due to other causes such as hypertension.

\section{DisCUSSION}

The general pattern of involvement of various regions of the heart was similar in this series to those previously reported by Williams et al. (1954). The left ventricle appeared to be affected to some degree in all our patients and the right ventricle somewhat less often; the mitral valve was affected in all but two patients and in more than half severe mitral regurgitation was diagnosed on clinical, radiological, and hæmodynamic grounds. The tricuspid valve was involved less often and the clinical evidence of a murmur accompanied by impairment of the descent of the base pattern of the right atrial pulse was only found in four instances.

The development of mitral regurgitation was accompanied by a raised left atrial pressure and a positive systolic pulsation. This picture was always accompanied clinically by a loud pansystolic murmur going up to the second sound, and radiating to the axilla and followed by a third heart sound. In these patients the left ventricular impulse was usually heaving and displaced to the left. Occasionally the impulse was not so well felt, presumably owing to the myocardial fibrosis constricting the ventricle: this diminished amplitude of pulsation of the left ventricle in association with mitral regurgitation was noted by Ball et al. (1954). Pulmonary hypertension, usually of moderate degree, was found in the majority of patients. In one, in whom there was predominant mitral regurgitation it was as high as $90 / 30 \mathrm{~mm}$. $\mathrm{Hg}$. The raised pulmonary arterial pressure was accompanied by a right ventricular heave and increase in the intensity of the pulmonary second sound with the X-ray picture of a prominent pulmonary conus. Bedford and Konstam (1946) in their description of a series of 40 cases of unexplained heart failure in African troops serving in the Middle East, noted accentuation of the pulmonary second sound and a prominent pulmonary artery and conus on the X-ray. More recently Abrahams (1959) has emphasized the association of endomyocardial fibrosis in West Africans with the clinical signs and findings at cardiac catheterization of pulmonary hypertension, and noted pulmonary arterial systolic pressures as high as $90 \mathrm{~mm}$. $\mathrm{Hg}$. The pulmonary hypertension accompanies a rise in the left atrial pressure, the latter being due either to the constricting effect of the fibrosis in the wall of the left ventricle or the mitral valvular incompetence. In none of our cases was there any evidence of significant mitral stenosis.

The right ventricular pulse was of considerable interest; all forms of pressure curve were observed, from normal to a grossly distorted form in which the curve resembled that obtained from the right atrium. The curves often showed a diastolic dip with a plateau form of raised end diastolic pressure; these closely resembled the right ventricular pressure pulse found in constrictive pericarditis (Hansen et al, 1951). In the extreme cases most of the function of the right heart appeared to be taken over by the right atrium. The raised mean venous pressure found in all these patients possibly contributed to the maintenance of the flow of blood through the lungs and into the left heart. The increase in diastolic dip and raised end diastolic pressure of the right ventricular pulse was always accompanied by a right ventricular third sound. 
Right heart cardiac catheterization, although confirming the clinical findings, probably does not contribute greatly to the diagnosis of endomyocardial fibrosis. A raised pulmonary capillary pressure could be associated with left ventricular failure from causes other than endomyocardial fibrosis, as was found in one patient studied with a high pulmonary capillary pressure and thought to have endomyocardial fibrosis: subsequent necropsy examination revealed a hypertrophied and dilated left ventricle but no macroscopic evidence of endomyocardial fibrosis. It is possible that a study of the right ventricular pulse may be of some value in separating endomyocardial fibrosis from constrictive pericarditis and other forms of cardiomyopathy. The presence of a grossly abnormal right ventricular pulse would favour the diagnosis of endomyocardial fibrosis.

\section{SUMMARY}

Fifteen patients with endomyocardial fibrosis in East Africans have been studied clinically and by phonocardiography, electrocardiography, and cardiac catheterization.

The disease particularly affects the endocardium and myocardium of the ventricles and may involve the mitral and tricuspid valves to produce valvular regurgitation. The lesions may occur separately or in any combination, and examples of each type are described.

The patients presented with signs of heart failure including breathlessness, palpitation, œdema, ascites, and hepatic pain. The clinical findings were those of heart failure associated with a constrictive picture of either the right ventricle or the left ventricle; mitral regurgitation was a common finding and tricuspid regurgitation was found less often.

Cardiac catheterization showed there was a raised left atrial pressure in the majority of cases with a moderately raised pulmonary artery pressure; in one instance the systolic pulmonary arterial pressure was as high as $90 \mathrm{~mm}$. Hg. The right ventricular pressure curve showed in most patients a raised end diastolic pressure and when the disease was advanced a grossly abnormal pulse with attenuated systolic wave. The right atrial pressure was usually raised and often resembled that found in constrictive pericarditis.

The relationship of the clinical picture to the hæmodynamic findings is discussed.

We should like to thank the Physicians at Mulago Hospital for help and access to their patients. We are grateful also to Professor Davies for his assistance and for the photographs of the pathological specimens, to Dr. Steiner for interpreting the X-rays, and to Mr. Robinson for his technical help. The work was supported in part by a grant from the East African Council for Medical Research.

\section{REFERENCES}

Abrahams, D. G. (1959). Lancet, 2, 111.

Ball, J. D., Davies, J. N. P., and Williams, A. W. (1954). Lancet, 1, 1049.

Bedford, D. E., and Konstam, G. L. S. (1946). Brit. Heart J., 8, 236.

Davies, J. N. P. (1948). E. Afr. med. J., 25, 10.

, and Ball, J. D. (1955). Brit. Heart J., 17, 337.

Edington, G. M. (1954). Trans. R. Soc. trop. Med. Hyg., 48, 419.

Hansen, A. T., Eskilden, P., and Gotzsche, H. (1951). Circulation, 3, 881.

Nagaratnam, N., and Dissanayake, R. U. P. (1959). Brit. Heart J., 21, 167.

O'Brien, W. (1954). Brit. med. J., 11, 899.

Gabe, I., and Shillingford, J. P. (1961). Brit. Heart J., 23, 271.

Somers, K., and Williams, A. W. (1960). Brit. Heart J., 22, 546.

Turner, P., and Manson-Bahr, P. E. C. (1960). Brit. Heart J., 22, 305.

Williams, A. W., Ball, J. D., and Davies, J. N. P. (1954). Trans. R. Soc. trop. Med. Hyg., $48,290$. 